Jurnal Bidan Cerdas
e-ISSN: 2654-9352 dan p-ISSN: 2715-9965
Volume 3 Nomor 2, 2021
DOI: 10.33860/jbc.v3i2.387

\title{
Gambaran Pengetahuan dan Sikap Ibu Hamil tentang Pemberian ASI Eksklusif
}

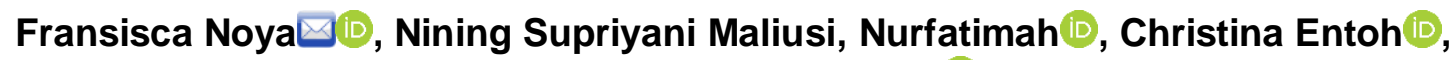 \\ Lisda Widianti Longgupa $\mathbb{D}$ \\ Prodi D-III Kebidanan Poso, Jurusan Kebidanan, Poltekkes Kemenkes Palu \\ $\triangle$ Email korespondensi: fransiscanoya@yahoo.co.id
}

\section{ARTICLE INFO}

Article History:

Received: 2021-02-10

Accepted: 2021-05-17

Published: 2021-06-10

\section{Kata Kunci:}

Pengetahuan; Sikap; ASl eksklusif.

\section{Keywords:}

Knowledge; Attitude; exclusive breastfeeding.

\begin{abstract}
ABSTRAK
Pendahuluan: Memberikan ASI ekslusif sampai bayi berusia 6 bulan mempunyai banyak kegunaan baik bagi ibu maupun anak. Kurangnya pengetahuan ibu tentang ASI eksklusif dapat mempengaruhi sikap ibu dalam pemberian ASI eksklusif. Cakupan pemberian ASI Eksklusif di Kelurahan Tegalrejo pada tahun 2016 sebesar 69\%. Mengalami penurunan pada 2017 menjadi 52\%, dan kembali terjadi penurunan pada 2018 menjadi 44\%. Cakupan pemberian ASI eksklusif di Kelurahan Tegalrejo belum mencapai target yang ditetapkan oleh Pemerintah Kabupaten Poso yaitu sebesar $50 \%$. Penelitian ini bertujuan untuk mengetahui gambaran pengetahuan dan sikap ibu hamil tentang pemberian ASI eksklusif. Metode: Penelitian ini menggunakan metode deskriptif kuantitatif. Populasi dalam penelitian ini adalah semua ibu hamil yang berdomisili di Kelurahan Tegalrejo berjumlah 33 ibu. Pengambilan sampel menggunakan teknik total sampling. Hasil: dari 33 responden terdapat 20 responden dengan pengetahuan baik, dan 28 responden dengan sikap positif. Kesimpulan: Kesimpulan dari penelitian ini adalah terbanyak responden mempunyai pengetahuan baik dan memiliki sifat positif.
\end{abstract}

ABSTRACT
Introduction: Providing exclusive breastfeeding for the first six months old
has many advantages both for baby and mother. Lack of mother
knowledge concerning exclusive breastfeeding can affect the mother
attitude towards exclusive breasfeeding. Exclusive breastfeeding coverage
in Tegalrejo Village in 2016 was $69 \%$. It decreased in 2017 to $52 \%$, then
decreased again in 2018 to $44 \%$. Exclusive breastfeeding coverage in
Tegalrego Village has not fulfilled the Poso Regency Government standard
which is 50\%. This study aims to describe the knowledge and attitudes of
pregnant women about exclusive breastfeeding. Methods: This research
used descriptive quantitative method. The study population were all
pregnant women who live in Tegalrejo Village totaling 33 mothers. The
sample was taken using total sample technique. Result: from 33
respondents there were 20 respondents with good knowledge, and 28
respondents with positive attitude. Conclusion: It can be concluded that
mainly respondents have a good knowledge and positive attitude towards
exclusive breastfeeding.

C 2021 by the authors. Submitted for possible open access publication under the terms and conditions of the Creative Commons Attribution (CC BY SA) license (https://creativecommons.org/licenses/by-sa/4.0/). 


\section{PENDAHULUAN}

Pemberian ASI secara eksklusif memiliki banyak manfaat antara lain meningkatkan jalinan kasih sayang antara ibu dan bayi, mencegah terjadinya perdarahan postpartum, mempercepat pemulihan kesehatan ibu serta sebagai kontrasepsi alamiah (Mabud, Mandang, and Mamuaya, 2014). Bayi yang tidak diberikan ASI eksklusif sampai usia enam bulan dapat menyebabkan diare, malnutrisi bahkan kematian (Irianto, 2014). Pemberian MP-ASI terlalu dini dapat mempengaruhi status gizi balita. Bayi yang tidak diberikan ASI ekslusif menjadi salah satu faktor penyebab malnutrisi pada anak (Friska \& Muflihah, 2014).

Pemberian ASI dianjurkan dalam jangka waktu 6 bulan. Upaya yang dapat dilakukan untuk menurunkan Angka Kematian Bayi adalah dengan melakukan Inisiasi Menyusu Dini (IMD) pada bayi baru lahir dan dilakukan secara eksklusif sampai bayi berusia 6 bulan. ASI mengandung imunoglobulin yang berguna bagi bayi untuk mencegah diare dan infeksi (Roesli, 2013).

Secara global, hanya 38\% bayi yang mendapat ASI eksklusif (Mohamed et al., 2018). Cakupan pemberian ASI eksklusif di Puskesmas Lawanga pada tahun 2016 sebesar 44,35 \%, mengalami peningkatan pada tahun 2017 yaitu sebesar $45,7 \%$ dan terjadi penurunan pada tahun 2018 yaitu sebesar 32,7 \% (Puskesmas Lawanga, 2018). Cakupan pemberian ASI Eksklusif di Kelurahan Tegalrejo tahun 2016 yaitu sebesar $69 \%$, mengalami penurunan pada tahun 2017 yaitu sebesar $52 \%$ dan kembali terjadi penurunan pada tahun 2018 yaitu sebesar 44 \% (Puskesmas Lawanga, 2018). Cakupan pemberian ASI eksklusif belum mencapai target yang ditetapkan oleh Pemerintah Kabupaten Poso yaitu sebesar 50\% (Dinas Kesehatan Kabupaten Poso, 2018).

Faktor predisposisi yang mempengaruhi pemberian ASI eksklusif yaitu pengetahuan dan sikap (Sjawie, Rumayar, and Korompis, 2019). Ibu dengan pengetahuan yang rendah mengenai ASI eksklusif dapat berdampak dalam praktik pemberian ASI (Yulianah et al., 2013). Beberapa hal yang menyebabkan Kurangnya pengetahuan ibu tentang pemberian ASI eksklusif yaitu informasi yang diterima kurang, tidak jelas dan kurangnya pemahaman terhadap informasi yang diperoleh (Yanuarini, Rahayu, and Prahitasari, 2017). Sikap ibu merupakan faktor yang menentukan kesediaan dan kesiapan ibu dalam memberikan ASI ekslusif. Sikap postif ibu mendorongnya untuk memberikan ASI secara eksklusif (Winly, Wenes, Malonda SH Nancy, Bolang, Alexasander SI, Kopatow, 2012). Sikap ibu dapat dipengaruhi oleh media massa dan orang lain serta pengetahuan terkait ASI eksklusif (Alimuddin et al., 2017). Penelitian ini bertujuan memberikan gambaran pengetahuan dan sikap ibu hamil tentang pemberian ASI eksklusif di Kelurahan Tegalrejo.

\section{METODE PENELITIAN}

Jenis dan desain dalam penelitian ini yaitu deskriptif kuantitatif.dan dilaksanakan di Kelurahan Tegalrejo Wilayah Kerja Puskesmas Lawanga mulai tanggal 7 sampai 22 April 2019. Populasi dalam penelitian ini yaitu semua ibu hamil yang berada di Kelurahan Tegalrejo Wilayah kerja Puskesmas Lawanga sebanyak 33 orang. Penentuan sampel secara total sampling.

Variabel dalam penelitian ini adalah pengetahuan dan sikap tentang pemberian ASI eksklusif. Definisi operasional pengetahuan yaitu kemampuan ibu menjawab pertanyaan yang ada dalam kuesioner tentang ASI eksklusif. Pengetahuan baik bila responden menjawab benar 76 - 100\% dan pengetahuan kurang bila responden menjawab benar $<76 \%$. Sikap yaitu pandangan atau respon ibu terhadap pemberian 
ASI eksklusif dinilai dari hasil kuesioner yang diberikan kepadanya. Sikap dikatakan positif bila jawaban responden $\geq$ nilai median, dan negatif bila $<$ nilai median. Kuesioner pengetahuan dan sikap dalam penelitian ini sudah baku yang diambil dari penelitian sebelumnya. Analisis dalam penelitian ini adalah analisis univariat dan bivariat untuk menggambarkan pengetahuan dan sikap ibu hamil tentang pemberian ASI Eksklusif.

\section{HASIL PENELITIAN}

Hasil yang diperoleh dalam penelitian ini adalah sebagai berikut:

Tabel 1. Distribusi Responden berdasarkan Umur, Pendidikan, Pekerjaan dan Paritas

\begin{tabular}{lcc}
\hline Karakteristik & Frekuensi & Persentase(\%) \\
\hline Umur & & \\
<20 Tahun & 2 & 6.1 \\
20-35 Tahun & 24 & 72.7 \\
> 35 Tahun & 7 & 21.2 \\
Pendidikan & & \\
SD & 5 & 15.2 \\
SMP & 10 & 30.3 \\
SMA & 15 & 45.4 \\
PT & 3 & 9.1 \\
Pekerjaan & & \\
IRT & 28 & 84.9 \\
PNS/TNI/POLRI & 1 & 3.0 \\
Pedagang & 4 & 12.1 \\
Paritas & & \\
Nulipara & 9 & 27.3 \\
Primipara & 10 & 30.3 \\
Multipara & 14 & 42.4 \\
\hline
\end{tabular}

Sumber: Data primer, 2019

Tabel 1 menunjukkan bahwa mayoritas berumur 20-35 tahun (72,7\%), pendidikan responden terbanyak berpendidikan SMA (45,4\%). Mayoritas pekerjaan responden adalah $\mathrm{IRT}(84,9 \%)$ dan paritas responden terbanyak yaitu multipara $(42,4 \%)$.

Tabel 2 Distribusi Pengetahuan dan Sikap lbu Hamil tentang ASI Eksklusif

\begin{tabular}{ccc}
\hline Variabel & Frekuensi & Persentase(\%) \\
\hline Pengetahuan & & \\
Baik & 20 & 60,6 \\
Cukup & 13 & 39,4 \\
Sikap & & \\
Positif & 28 & 84,9 \\
Negatif & 5 & 15,1 \\
\hline
\end{tabular}

Sumber: Data primer, 2019

Pada tabel 2, mayoritas pengetahuan ibu adalah baik (60,6\%) dan sikap terbanyak tentang pemberian ASI eksklusif adalah positif $(84,9 \%)$. 
Tabel 3 Distribusi Pernyataan Pengetahuan Ibu Hamil tentang Pemberian ASI Eksklusif

\begin{tabular}{|c|c|c|c|c|c|}
\hline \multirow{3}{*}{ No } & \multirow{3}{*}{ Pernyataan } & \multicolumn{4}{|c|}{$\begin{array}{c}\text { Jumlah jawaban yang } \\
\text { dipilih responden }\end{array}$} \\
\hline & & \multicolumn{2}{|c|}{ Benar } & \multicolumn{2}{|c|}{ Salah } \\
\hline & & $\mathbf{n}$ & $\%$ & $\mathbf{n}$ & $\%$ \\
\hline 1 & $\begin{array}{l}\text { ASI mengandung zat antibody (kekebalan } \\
\text { untuk tubuh bayi) }\end{array}$ & 33 & 100,0 & 0 & 0,0 \\
\hline 2 & $\begin{array}{l}\text { Manfaat ASI bagi bayi adalah makanan } \\
\text { utama, terbaik dan merupakan komposisi } \\
\text { ideal untuk bayi }\end{array}$ & 32 & 97,0 & 1 & 3,0 \\
\hline 3 & $\begin{array}{l}\text { Manfaat ASI bagi bayi dapat mengurangi } \\
\text { resiko infeksi lambung dan usus, } \\
\text { sembelit/diare, serta alergi dan membuat bayi } \\
\text { lebih kebal terhadap penyakit ketimbang bayi } \\
\text { yang tidak diberi ASI }\end{array}$ & 24 & 72.7 & 9 & 27.3 \\
\hline 4 & $\begin{array}{l}\text { Manfaat ASI bagi bayi adalah sulit dicerna, } \\
\text { tidak steril, dan mengurangi perkembangan } \\
\text { otak (IQ) }\end{array}$ & 30 & 90.9 & 3 & 9.1 \\
\hline 5 & $\begin{array}{l}\text { ASI tidak dapat melindungi bayi terhadap } \\
\text { penyakit seperti Diare dan Infeksi Saluran } \\
\text { Pernafasan atas (ISPA) }\end{array}$ & 28 & 84.8 & 5 & 15.2 \\
\hline 6 & $\begin{array}{l}\text { Manfaat ASI bagi ibu adalah dapat } \\
\text { mempercepat kondisi ibu untuk kembali pulih } \\
\text { setelah melahirkan dan mengurangi risiko } \\
\text { perdarahan }\end{array}$ & 24 & 72.7 & 9 & 27.3 \\
\hline 7 & $\begin{array}{l}\text { Memberikan ASI pada bayi dapat membuat } \\
\text { ibu menjadi gemuk dan membuat ibu repot } \\
\text { karena tidak bisa pergi meninggalkan anak }\end{array}$ & 28 & 84.8 & 5 & 15.2 \\
\hline 8 & $\begin{array}{l}\text { Susu formula mempunyai kandungan gizi } \\
\text { yang lebih baik dibanding ASI }\end{array}$ & 28 & 84.8 & 5 & 15.2 \\
\hline 9 & $\begin{array}{l}\text { Kandungan yang terdapat dalam ASI belum } \\
\text { lengkap jika tidak diselingi dengan pemberian } \\
\text { makanan/minuman lain seperti susu formula } \\
\text { dan buah-buahan pada bayi umur } 0-6 \text { bulan }\end{array}$ & 21 & 63.6 & 12 & 36.4 \\
\hline 10 & $\begin{array}{l}\text { ASI dapat memperkuat ikatan batin antara ibu } \\
\text { dan anak }\end{array}$ & 33 & 100,0 & 0 & 0,0 \\
\hline 11 & $\begin{array}{l}\text { ASI sebagai nutrisi mengandung lemak, } \\
\text { karbohidrat, protein, vitamin, garam dan } \\
\text { mineral }\end{array}$ & 30 & 90.9 & 3 & 9.1 \\
\hline 12 & $\begin{array}{l}\text { ASI eksklusif adalah pemberian air susu saja } \\
\text { (tanpa makanan/minuman pendamping } \\
\text { termasuk air putih maupun susu formula } \\
\text { kecuali sirop obat) selama enam (6) bulan }\end{array}$ & 27 & 81.8 & 6 & 18.2 \\
\hline 13 & $\begin{array}{l}\text { Bayi cukup diberi ASI saja tanpa } \\
\text { makanan/minuman tambahan lain sampai } \\
\text { usia } 4 \text { bulan }\end{array}$ & 14 & 42.4 & 19 & 57.6 \\
\hline 14 & $\begin{array}{l}\text { Suami atau keluarga memberitahu pada ibu } \\
\text { bahwa bayi usia } 0-6 \text { bulan hanya diberikan } \\
\text { ASI saja tanpa boleh makanan lain seperti } \\
\text { pisang, susu botol, madu, atau bubur tim }\end{array}$ & 23 & 69.7 & 10 & 30.3 \\
\hline
\end{tabular}




\begin{tabular}{|c|c|c|c|c|c|}
\hline \multirow{3}{*}{ No } & \multirow{3}{*}{ Pernyataan } & \multicolumn{4}{|c|}{$\begin{array}{l}\text { Jumlah jawaban yang } \\
\text { dipilih responden }\end{array}$} \\
\hline & & \multicolumn{2}{|c|}{ Benar } & \multicolumn{2}{|c|}{ Salah } \\
\hline & & $\mathbf{n}$ & $\%$ & $\mathbf{n}$ & $\%$ \\
\hline 15 & $\begin{array}{l}\text { ASI bagi bayi umur 0-6 bulan adalah makanan } \\
\text { pelengkap yang dapat diselingi dengan } \\
\text { makanan/minuman lain seperti buah-buahan } \\
\text { dan susu formula }\end{array}$ & 25 & 75.8 & 8 & 24.2 \\
\hline 16 & $\begin{array}{l}\text { Pelaksanaan Inisiasi Menyusui Dini adalah } \\
\text { meletakkan bayi baru lahir di dada ibu, kontak } \\
\text { kulit bayi ke kulit ibunya paling sedikit } 1 \text { jam, } \\
\text { mengetahui tanda-tanda bayi yang siap } \\
\text { menyusui serta bayi menemukan puting } \\
\text { susunya tanpa dibantu sampai selesai } \\
\text { menyusu }\end{array}$ & 33 & 100,0 & 0 & 0,0 \\
\hline 17 & $\begin{array}{l}\text { Payudara kecil tidak akan menghasilkan } \\
\text { cukup ASI, sehingga bayi harus diberi susu } \\
\text { kaleng/formula }\end{array}$ & 16 & 48.5 & 17 & 51.5 \\
\hline 18 & $\begin{array}{l}\text { Manfaat ASI bagi ibu adalah meningkatkan } \\
\text { resiko kanker rahim dan kanker payudara }\end{array}$ & 22 & 66.7 & 11 & 33.3 \\
\hline 19 & $\begin{array}{l}\text { Manfaat ASI bagi keluarga adalah untuk } \\
\text { penghematan baik dari segi uang maupun } \\
\text { waktu dan tenaga, penjarangan kehamilan, } \\
\text { dan sangat praktis }\end{array}$ & 33 & 100,0 & 0 & 0,0 \\
\hline 20 & $\begin{array}{l}\text { ASI pertama (yang berwarna kekuningan) } \\
\text { tidak baik bagi bayi }\end{array}$ & 18 & 54.5 & 15 & 45.5 \\
\hline
\end{tabular}

Sumber: Data primer, 2019

Tabel 3 menunjukkan bahwa dari 33 responden yang banyak menjawab benar pada kuesioner adalah pernyataan soal nomor 1, 10, 16 dan 19 yaitu sebanyak 33 responden $(100 \%)$, dan yang banyak menjawab salah pada soal nomor 13 yaitu sebanyak 19 responden (57.6\%).

Tabel 4 Distribusi Pernyataan Sikap Ibu Hamil tentang Pemberian ASI Eksklusif

\begin{tabular}{|c|c|c|c|c|c|}
\hline \multirow{3}{*}{ No } & \multirow{3}{*}{ Pernyataan } & \multicolumn{4}{|c|}{$\begin{array}{l}\text { Jumlah jawaban yang dipilih } \\
\text { responden }\end{array}$} \\
\hline & & \multicolumn{2}{|c|}{ Setuju } & \multicolumn{2}{|c|}{ Tidak setuju } \\
\hline & & $\mathbf{n}$ & $\%$ & $\mathbf{n}$ & $\%$ \\
\hline 1 & $\begin{array}{l}\text { Saya setuju bayi cukup diberikan ASI saja tanpa } \\
\text { minuman dan makanan tambahan lainnya sampai } \\
\text { berusia } 4 \text { bulan }\end{array}$ & 16 & 48.5 & 17 & 51.5 \\
\hline 2 & $\begin{array}{l}\text { Saya setuju bayi cukup diberikan ASI saja sampai } \\
\text { dengan umur } 6 \text { bulan }\end{array}$ & 22 & 66.7 & 11 & 33.3 \\
\hline 3 & $\begin{array}{l}\text { Saya setuju memberikan susu formula/ susu } \\
\text { kaleng kepada bayi lebih praktis daripada } \\
\text { memberikan ASI }\end{array}$ & 30 & 90.9 & 3 & 9.1 \\
\hline 4 & $\begin{array}{l}\text { Saya menolak memberikan susu kaleng sampai } \\
\text { bayi berumur } 6 \text { bulan }\end{array}$ & 24 & 72.7 & 9 & 27.3 \\
\hline 5 & $\begin{array}{l}\text { Saya setuju bahwa kandungan gizi yang terdapat } \\
\text { dalam ASI lebih baik daripada susu kaleng } \\
\text { manapun }\end{array}$ & 32 & 97,0 & 1 & 3,0 \\
\hline
\end{tabular}




\begin{tabular}{|c|c|c|c|c|c|}
\hline \multirow{3}{*}{ No } & \multirow{3}{*}{ Pernyataan } & \multicolumn{4}{|c|}{$\begin{array}{l}\text { Jumlah jawaban yang dipilih } \\
\text { responden }\end{array}$} \\
\hline & & \multicolumn{2}{|c|}{ Setuju } & \multicolumn{2}{|c|}{ Tidak setuju } \\
\hline & & $\mathbf{n}$ & $\%$ & $\mathbf{n}$ & $\%$ \\
\hline 6 & $\begin{array}{l}\text { Saya sependapat dengan orang tua/mertua untuk } \\
\text { memberikan makanan/ minuman tambahan } \\
\text { selain ASI setelah bayi berusia } 6 \text { bulan }\end{array}$ & 31 & 93.9 & 2 & 6.1 \\
\hline 7 & $\begin{array}{l}\text { Saya setuju ASI saja tidak mencukupi kebutuhan } \\
\text { bayi usia } 0-6 \text { bulan }\end{array}$ & 24 & 72.7 & 9 & 27.3 \\
\hline 8 & $\begin{array}{l}\text { Saya setuju memberikan madu atau air sebelum } \\
\text { bayi berumur } 6 \text { bulan }\end{array}$ & 28 & 84.8 & 5 & 15.2 \\
\hline 9 & $\begin{array}{l}\text { Saya setuju bagi ibu yang bekerja ASI dapat } \\
\text { diganti dengan susu formula }\end{array}$ & 24 & 72.7 & 9 & 27.3 \\
\hline 10 & $\begin{array}{l}\text { Saya setuju apabila ibu berpergian/bekerja, ASI } \\
\text { dapat diperah dan diberikan oleh siapapun } \\
\text { kepada bayi dengan menggunakan sendok }\end{array}$ & 22 & 66.7 & 11 & 33.3 \\
\hline
\end{tabular}

Berdasarkan tabel 4. menunjukkan dari 33 responden yang banyak menjawab benar pada kuesioner adalah pernyataan soal nomor 5 yaitu sebanyak 32 responden (97\%), dan yang banyak menjawab salah pada soal nomor 1 yaitu sebanyak 17 responden (51.5\%).

Tabel 5. Distribusi Pengetahuan dan Sikap Ibu Hamil tentang Pemberian ASI Eksklusif di Kelurahan Tegalrejo Wilayah Kerja Puskesmas Lawanga

\begin{tabular}{|c|c|c|c|c|c|c|}
\hline \multirow{3}{*}{ Pengetahuan } & \multicolumn{4}{|c|}{ Sikap } & \multirow{2}{*}{\multicolumn{2}{|c|}{ Jumlah }} \\
\hline & \multicolumn{2}{|c|}{ Positif } & \multicolumn{2}{|c|}{ Negatif } & & \\
\hline & $\mathbf{n}$ & $\%$ & $\mathbf{n}$ & $\%$ & $\mathbf{n}$ & $\%$ \\
\hline Baik & 20 & 100,0 & 0 & 0,0 & 20 & 100 \\
\hline Cukup & 8 & 61,5 & 5 & 38,5 & 13 & 100 \\
\hline Jumlah & 28 & 84.8 & 5 & 15.2 & 33 & 100 \\
\hline
\end{tabular}

Sumber : Data primer, 2019

Tabel 5 terlihat distribusi frekuensi berdasarkan pengetahuan dan sikap terbanyak yaitu kategori baik dan memiliki sikap positif (100\%).

\section{PEMBAHASAN}

Adanya ide, gagasan dan pemikiran serta konsep yang dipunyai manusia melalui penginderaan terhadap lingkungannya membentuk pengetahuan seseorang. Pengetahuan membentuk perilaku/tindakan manusia (Keraf, 2009). Hasil penelitian menunjukkan responden memiliki pengetahuan baik sejumlah 20 orang (100\%). Ibu yang memiliki pengetahuan kurang ditunjukan oleh jawaban ibu yang memilki skor rendah. Contohnya untuk variabel pengetahuan pernyataan nomor 13, responden paling banyak belum mengetahui definisi ASI eksklusif. Terkait pernyataan mengenai bayi cukup diberi ASI saja tanpa makanan/minuman tambahan lain sampai usia 4 bulan ternyata masih terdapat 19 responden yang menjawab dengan jawaban benar. Padahal pernyataan tersebut adalah salah. Menurut asumsi peneliti hal ini dapat diakibatkan oleh beberapa faktor seperti seperti pengaruh media massa, pengaruh orang lain yang dianggap penting misalnya gencarnya promosi susu formula dan pendidikan responden.

Pendidikan dari ibu dengan pengetahuan kurang hanya tamat sekolah dasar. Hal ini menyebabkan pengetahuan masih sangat rendah, dan pengetahuan responden 
juga dapat diperoleh dari pendidikan informal seperti penyuluhan-penyuluhan, melihat media cetak dan elektronik. namun responden kurang menerima informasi dan kurangnya motivasi dari diri untuk mengetahui hal tersebut. Pendidikan tinggi yang dimiliki seseorang membuatnya memiliki banyak pengetahuan dibanding seseorang dengan pendidikan rendah (Sjawie, Rumayar, and Korompis, 2019). Dalam penelitian ini responden dengan pendidikan tinggi pemahaman mengenai ASI eksklusif baik.

Sesuai pendapat Notoatmodjo, seseorang dengan jenjang pendidikan tinggi memiliki perilaku yang lebih baik karena mampu mencerna informasi yang diterimanya (Notoatmodjo, 2012). Hasil ini sesuai penelitian (Suryaningtya \& A, 2010), bahwa ibu yang memiliki pengetahuan yang baik tentang ASI eksklusif akan memberikan ASI Eksklusif pada bayinya. Rendahnya pengetahuan ibu tentang ASI eksklusif, maka semakin kecil pula kesempatan ibu dalam memberikan ASI eksklusif. Seseorang yang lebih sering mendengar atau memperoleh informasi semakin sering terpapar informasi maka pengetahuan akan bertambah pula (Sukmadinata and Nana, 2013). Ibu hamil yang telah mendapat penyuluhan tentang pemberian ASI eksklusif yang optimal cenderung memiliki pengetahuan yang baik tentang pemberian ASI eksklusif (Hashim et al., 2017). Penyuluhan menggunakan audio-visual dapat meningkatkan pengetahuan ibu tentang ASI eksklusif (Idris \& Enggar, 2020).

Sikap adalah kesiapan atau kesediaan untuk bertindak, dan bukan merupakan pelaksanaan motif tertentu. Sikap bukan merupakan suatu tindakan atau aktifitas, akan tetapi merupakan predisposisi tindakan suatu perilaku (Notoatmodjo, 2012). Berdasarkan hasil penelitian responden terbanyak memiliki sikap positif $(84.4 \%)$. Ibu yang memiliki sikap negatif ditunjukan oleh jawaban ibu yang memiliki skor rendah. Contohnya untuk variabel sikap pernyataan nomor 1 , responden paling banyak belum mengetahui definisi ASI eksklusif. Terkait pernyataan mengenai saya setuju bayi cukup diberikan ASI saja tanpa minuman dan makanan tambahan lainnya sampai berusia 4 bulan ternyata masih terdapat 17 responden yang menjawab dengan jawaban benar. Padahal pernyataan tersebut adalah salah. Hal ini dapat diakibatkan oleh beberapa faktor seperti pengaruh media massa, pengaruh orang lain yang dianggap penting, pendidikan, dan usia responden.

Hasil penelitian ini sejalan dengan penelitian Sahara, lbu yang berusia 20-35 tahun terbanyak memiliki sikap positif dalam memberikan ASI eksklusif karena sudah ada pengalaman sebelumnya, selain itu juga karena pengetahuannya baik (Sahara, 2013). Hasil di atas sesuai pendapat Ramadhani menyatakan sikap merupakan hasil dari proses pengetahuan terhadap suatu objek tertentu (Ramadhani, 2009). Ibu yang mempunyai sikap postif dalam memberikan ASI eksklusif semuanya memiliki pengetahuan baik (100\%). Sejalan dengan hasil penelitian yang dilakukan Mabud, dkk yang mengatakan sikap ibu akan semakin positif untuk mendukung dalam pemberian ASI jika didukung oleh pengetahuannya yang baik (Mabud et al., 2014).

Sejalan dengan hasil penelitian Nasrah menunjukkan bahwa terbanyak ibu memiliki sikap postif dalam pemberian ASI eksklusif (Nasrah, 2015). Sejalan dengan hasil penelitian Kitiyo dkk, ibu yang memiliki pengetahuan yang baik akan memiliki sikap yang positif terhadap pemberian ASI eksklusif (Kitiyo et al., 2020). Adanya dukungan keluarga dan lingkungan sekitar serta informasi yang diterima ibu saat hamil terkait ASI eksklusif dapat membentuk sikap positif ibu untuk memberikan ASI eksklusif. Hasil penelitian Mogre dkk menunjukkan sebagian besar ibu berkonsultasi tentang kesulitan menyusui dengan keluarga dan orang sekitarnya daripada ke petugas kesehatan (Mogre et al., 2016). Informasi dari keluarga dan orang sekitar tidak menjamin ibu untuk memiliki sikap dan praktik yang baik dalam pemberian ASI eksklusif. 


\section{SIMPULAN DAN SARAN}

Peneliti menyimpulkan bahwa pengetahuan responden terbanyak baik dan memiliki sikap positif untuk memberikan ASI eksklusif. Peneliti mengharapkan agar puskesmas dapat meningkatkan lagi program pemberian ASI eksklusif di wilayah kerjanya dan memberikan penyuluhan yang lebih spesifik melalui komunikasi (KIE) langsung oleh petugas kesehatan di desa, seperti bidan desa agar mengarahkan kader posyandu untuk melakukan penyuluhan ASI eksklusif dan untuk ibu hamil yang tidak hadir saat posyandu, diharapkan bidan dan kader dapat melakukan kunjungan rumah untuk melakukan penyuluhan mandiri kepada ibu.

\section{UCAPAN TERIMA KASIH}

Terima kasih diucapkan kepada kepala Puskesmas Lawanga serta Bidan koordinator yang sudah mengizinkan serta membantu selama penelitian ini.

\section{DAFTAR PUSTAKA}

Alimuddin, N. M. N., Kapantow, N. H., \& Kawengian, S. E. S. (2017). Hubungan Antara Pengetahuan Dan Sikap Ibu Dengan Pemberian Asi Eksklusif Pada Bayi Berusia 6-12 Bulan Di Wilayah Kerja Puskesmas Bailang Kota Manado. Kesmas, 6(4), 1-7. https://ejournal.unsrat.ac.id//index.php/kesmas/article/view/23088

Dinas Kesehatan Kabupaten Poso. (2018). Profil Kesehatan Kabupaten Poso tahun 2018.

Friska, M., \& Muflihah, I. (2014). Faktor Risiko Kejadian Stunting Pada Balita Usia 12 Bulan Di Desa Purwokerto Kecamatan Patebon Kabupaten Kendal. Journal of Nutrition College, 3(2), 16-25. https://doi.org/http://dx.doi.org/10.14710/jnc.v3i2.5437

Hashim, T. H., Mgongo, M., Katanga, J., Uriyo, J. G., Damian, D. J., Stray-Pedersen, B., Wandel, M., \& Msuya, S. E. (2017). Predictors of appropriate breastfeeding knowledge among pregnant women in Moshi Urban, Tanzania: A cross-sectional study. International Breastfeeding Journal, 12(1), 1-8. https://doi.org/10.1186/s13006-017-0102-4

Idris, I., \& Enggar, E. (2020). Pengaruh Penyuluhan Menggunakan Audio Visual tentang ASI Eksklusif terhadap Pengetahuan dan Sikap Ibu Hamil. Jurnal Bidan Cerdas, 1(2), 51-58. https://doi.org/10.33860/jbc.v1i2.120

Irianto, K. (2014). IImu Kesehatan Anak (Pediatri). Alfabeta. https://opac.perpusnas.go.id/DetailOpac.aspx?id=910439

Keraf, S. (2009). Ilmu Pengetahuan: Sebuah Tinjauan Filosofis. Kanisius.

Kitiyo, P., Kimiywe, J., \& Ogada, I. (2020). Exclusive Breastfeeding Knowledge And Attitudes Among Mothers In Mother-To-Mother Support Groups In Kitui County, Kenya. International Journal of Health Sciences and Research (Www.ljhsr.Org), 10(2), 208-214. https://www.ijhsr.org/IJHSR_Vol.10_Issue.2_Feb2020/32.pdf

Mabud, N., Mandang, J., \& Mamuaya, T. (2014). Hubungan Pengetahuan, Pendidikan, Paritas dengan Pemberian ASI eksklusif di Puskesmas Bahu Kecamatan Malalayang Kota Manado. Jurnal IImiah Bidan, 2(2), 51-56. https://ejurnal.poltekkesmanado.ac.id/index.php/jidan/article/view/316

Mogre, V., Dery, M., \& Gaa, P. K. (2016). Knowledge, attitudes and determinants of exclusive breastfeeding practice among Ghanaian rural lactating mothers. International Breastfeeding Journal, 11(1), 1-8. https://doi.org/10.1186/s13006-016-0071-z

Mohamed, M. J., Ochola, S., \& Owino, V. O. (2018). Comparison of knowledge, attitudes and practices on exclusive breastfeeding between primiparous and multiparous mothers attending Wajir District hospital, Wajir County, Kenya: A cross-sectional analytical study. International Breastfeeding Journal, 13(1), 1-10. https://doi.org/10.1186/s13006-0180151-3

Nasrah. (2015). Hubungan Pengetahuan dan Sikap Ibu dalam Pemberian ASI Eksklusif di Puskesmas Kasihan II Bantul Yogyakarta [STIKES 'Aisyiyah Yogyakarta]. http://digilib.unisayogya.ac.id/622/ 
Notoatmodjo, S. (2012). Ilmu perilaku Kesehatan. Rineka Cipta.

Puskesmas Lawanga. (2018). Profil Puskesmas Lawanga.

Ramadhani, K. (2009). Gambaran Pengetahuan Sikap lbu dalam Pemberian Makanan Keluarga. Rineka Cipta.

Roesli, U. (2013). Mengenal ASI Eksklusif. PT Pustaka Pembangunan Swadaya Nusantara. https://books.google.co.id/books?id=zWDmh8QBlkMC\&printsec=frontcover\&hl=id\#v=on epage\&q\&f=false

Sahara, D. (2013). Hubungan Umur Ibu dan Paritas dengan Pemberian ASI Eksklusif pada Bayi Berusia 0-6 Bulan di Puskesmas Pembina Palembang [Poltekkes Kemenkes Palembang]. https://kink.onesearch.id/Record/IOS3411.slims-537

Sjawie, W. A., Rumayar, A. A., \& Korompis, G. E. C. (2019). Hubungan Antara Pengetahuan dan Sikap lbu dengan Pemberian ASI Eksklusif di Wilayah Kerja Puskesmas Tuminting Kota Manado. Jurnal KESMAS, 8(7), 298-304. https://ejournal.unsrat.ac.id/index.php/kesmas/article/view/26607

Sukmadinata, \& Nana, S. (2013). Metode Penelitian Pendidikan. PT Remaja Rosdakarya.

Suryaningtya, A., \& A, W. N. (2010). Hubungan antara tingkat Pengetahuan lbu dengan Perilaku Pemberian ASI di Puskesmas Nguter. Jurnal Kesehatan, 3(3), 112-119. https://publikasiilmiah.ums.ac.id/handle/11617/3619

Wenas, W., Malonda, N. S. H., Bolang, A. S. L., \& Kapantow, ova H. (2012). Hubungan Antara pengetahuan dan Sikap Ibu meyusui dengan pemberian ASI Eksklusif di wilayah kerja puskesmas Tompaso Kecamatan Tompaso [Universitas Sam RatulangiManado]. In Bidang Minat Gizi Universitas Sam Ratulangi Manado. https://adoc.pub/pendahuluanmakanan-pertama-dan-utama-bagi-bayi-adalah-air-s.html

Yanuarini, T. A., Rahayu, D. E., \& Prahitasari, E. (2017). Hubungan Pengetahuan Dengan Sikap Ibu dalam Pemberian ASI Eksklusif di Wilayah Kerja Puskesmas Pranggang Kabupaten Kediri. Jurnal IImu Kesehatan, 3(1), 1. https://doi.org/10.32831/jik.v3i1.39

Yulianah, N., Bahar, B., \& Salam, A. (2013). Hubungan antara pengetahuan, sikap, dan kepercayaan ibu dengan pemberian ASI eksklusif di wilayah kerja puskesmas Bonto Cani kabupaten Bone tahun 2013 [Universitas Hasanuddin]. https://core.ac.uk/display/25490916 